\title{
STEROID CATARACT
}

\author{
BY \\ C. FÜRST $\dagger$, W. K. SMILEY, AND B. M. ANSELL \\ M.R.C. Rheumatism Research Unit, Canadian Red Cross Memorial Hospital, \\ Taplow, Maidenhead, Berks.
}

Black, Oglesby, von Sallmann, and Bunim (1960) first described posterior subcapsular lens opacities in seventeen of 44 patients suffering from rheumatoid arthritis who were maintained on long-term corticosteroid therapy, and later (Oglesby, Black, von Sallmann, and Bunim, 1961) they expanded the series to include patients suffering from a variety of rheumatic disorders. Subsequently other workers have described single cases or series (Hart, Casey, and O'Riordan, 1961; Pfahl, Makley, McCoy, and Rothermich, 1961; Toogood, Dyson, Thompson, and Mularchyk, 1962) covering many of the disorders frequently treated with corticosteroid therapy. When Crews (1963) compared 79 patients treated with corticosteroid therapy, of whom 52 were suffering from classical rheumatoid arthritis, with 171 patients who had never received corticosteroid therapy, of whom 34 had rheumatoid arthritis, he found bilateral posterior subcapsular lens opacities in 25 of the steroid-treated group and five in the nonsteroid group; he considered that those in the steroid group had features differentiating them from the control group.

None of these studies contained an appreciable number of patients suffering from juvenile rheumatoid arthritis (Still's disease), and it was therefore felt worthwhile to review a series of such patients maintained on corticosteroid therapy and to compare them with adult patients.

\section{Materials and Methods}

At this Unit a combined eye and joint clinic is held primarily for reviewing all patients with Still's disease and patients who are on antimalarial therapy to exclude eye complications, and also for easy referral of rheumatic patients who have ocular symptoms or signs. For the

\footnotetext{
* Presented at a meeting of the Heberden Society on April 3, 1965.

+ Research Fellow present address-Medical Department, BAD RAGAZ, Switzerland.
}

purpose of this study it was decided to re-examine all cases of Still's disease who had been on maintenance corticosteroid therapy for at least the preceding year. Their names were obtained from the special register which is kept for all patients who receive more than 3 months of corticosteroid therapy. There were 53 patients suffering from definite Still's disease (criteria of Ansell and Bywaters, 1959*) who had never had any evidence of iridocyclitis and four who had iridocyclitis affecting one eye only. An equivalent number of patients suffering from classical rheumatoid arthritis (A.R.A. criteria, 1959) who had also been on corticosteroid therapy for a minimum of one year were asked to attend the combined clinic; these were selected only by reason of living within easy access of the base hospital. A control series comprised 48 patients with classical rheumatoid arthritis who attended the combined clinic on account of anti-malarial therapy during the period of the study and had never received corticosteroid therapy.

On this occasion, as part of their routine clinical check, the patients were asked for eye symptoms and then examined with an ophthalmoscope (using a +12 dioptre lens) by the clinician, whose findings were recorded independently. The patients were then reviewed by the ophthalmologist of the team (W.K.S.); the pupils were dilated and examined with the slit-lamp microscope. Viewed with a suitable plus lens with the ophthalmoscope, even an early steroid cataract can usually be detected in a dark room without dilating the pupil and without specialized ophthalmic training; it will be seen as a dark spot perhaps $1 \mathrm{~mm}$. or less in diameter in the centre of the pupil against the red reflex of the retina. By parallax the spot can be confirmed to lie in the posterior cortex. At this early stage the vision is little affected but later, as the opacity increases in size, detection becomes obvious and sight increasingly blurred. When examined with the slit-lamp microscope with the pupil dilated, the opacity can be recognized at a very early stage by retro-illumination. By focal illumination it is seen to lie subcapsularly

* Criteria for diagnosis of definite Still's disease. Onset of poly arthritis before the age of $\mathbf{1 6}$ years involving four or more joints for a minimum of 3 months or, when less than four joints are involved, a biopsy of synovial membrane showing histology compatible with a diagnosis of rheumatoid arthritis in the absence of evidence of other related diseases, such as rheumatic fever, psoriasis, systemic lupus erythematosus, etc. 
in the posterior cortex on or near the axial line as one or more discrete grey dots with or without adjacent vacuoles. Polychromatic lustre may be present or absent. Later the dots coalesce into a plaque which gradually spreads peripherally and axially. The cataract in one of our cases, however, followed a different and unusual pattern.

Case 7, a boy who came under our care and commenced systemic corticosteroid therapy in 1961 at the age of 4 years, had severe Still's disease of 3 years' duration. At this time the right eye was entirely normal and the vision 6/6. The left eye was blind because of old iridocyclitis, band keratopathy, and complicated cataract-the typical triad of Still's disease (Smiley, May, and Bywaters, 1957). In early December, 1964, the patient noticed some fleeting fluctuation in the vision of the right eye but nothing abnormal was found on examination. At this stage he had been on systemic prednisone for $3 \frac{3}{4}$ years, and although he had received $20 \mathrm{mg}$. daily for 14 days initially he was rapidly reduced to $5 \mathrm{mg}$. daily and later to $4 \mathrm{mg}$. daily, the mean daily dosage being $4 \cdot 7$, and the total amount given up to December, 1964, being $6 \cdot 2 \mathrm{~g}$. He went home on holiday for 10 days at Christmas and during this time his sight dramatically deteriorated. When he returned to hospital early in January, 1965, his sight was a blurred 6/60 with a myopic correction and the right lens was cataractous. Unlike the usual early steroid cataract, there was a diffuse haze throughout the lens cortex composed of tiny punctate opacities, with the suggestion of a denser plaque at the posterior pole. The retina could be seen only vaguely through the lens haze. The eye was free from any evidence of inflammation. During the next few months the generalized lens haze became less dense and more typical steroid opacities developed subcapsularly at the posterior and anterior poles. For some time before and since the development of the cataract the arthritis had been more active, the plasma proteins have shown a progressive fall in serum albumin, proteinuria has developed, and he has become nephrotic as a result of amyloidosis. How far his general deterioration predisposed to the unusual steroid cataract it is impossible to say.

Before a diagnosis of steroid cataract can be made, other causes of posterior subcapsular opacities have to be considered, e.g. familial, traumatic, complicated, toxic, radiational, and senile. It is only in cases in which these factors have been excluded and which have the characteristic appearance (Crews, 1963) that a firm diagnosis can be established.

\section{Results}

52 of the 53 children without iridocylitis together with the four cases of Still's disease with unilateral iridocyclitis and 57 cases of classical rheumatoid arthritis were examined during this study. Among these 113 patients on corticosteroid therapy, thirteen were found to have early lens opacities, all of which were subsequently confirmed as typical posterior subcapsular steroid cataracts. No cataract was found that had not been suspected by the rheumatologist. The cataracts were present in similar numbers among the patients with Still's disease and those with rheumatoid arthritis, giving an overall incidence of 11 per cent. (Table I). No similar cataract was found in the 48 patients with classical or definite rheumatoid arthritis who were on antimalarial therapy and had never received corticosteroid therapy.

TABLE I

INCIDENCE OF POSTERIOR SUBCAPSULAR CATARACT IN 113 PATIENTSON LONG-TERM CORTICOSTEROID THERAPY

\begin{tabular}{|c|c|c|c|c|}
\hline \multirow[t]{2}{*}{ Diagnosis } & \multicolumn{2}{|c|}{$\begin{array}{l}\text { Posterior } \\
\text { Subcapsular } \\
\text { Cataract }\end{array}$} & \multirow{2}{*}{$\begin{array}{l}\text { Total } \\
\text { No. of } \\
\text { Cases }\end{array}$} & \multirow{2}{*}{$\begin{array}{c}\text { Percentage } \\
\text { with } \\
\text { Posterior } \\
\text { Subcapsular } \\
\text { Cataract }\end{array}$} \\
\hline & Present & Absent & & \\
\hline Total & 13 & 100 & 113 & 11 \\
\hline Still's Disease & 7 & 49 & 56 & $12 \cdot 5$ \\
\hline Rheumatoid Arthritis & 6 & 51 & 57 & $10 \cdot 5$ \\
\hline
\end{tabular}

With the exception of Case 7 in whom there was only one eye at risk because of chronic iridocyclitis in the other, all patients had bilaterial cataracts. As patients suspected of having steroid cataracts had been checked at the combined clinic before this study was commenced, the duration of therapy before the first sign of cataract appeared had already been established in some of them. In only one case was there evidence of a very marked interval between the involvement of the two eyes. This was Case 2, a girl suffering from Still's disease, who had been noted to have a cataract in one eye at the age of 6 after only $1 \frac{1}{4}$ years of therapy, the second eye not becoming involved until $2 \frac{1}{2}$ years later. This is the earliest instance in which cataract was detected in our series. The other cases among the children occurred at intervals varying up to $5 \frac{3}{4}$ years from the onset of therapy. The mean daily dose given to these patients, calculated as $\mathrm{mg}$. prednisone, had varied between 4.7 and $20.2 \mathrm{mg}$. and the total amount given before the development of cataract varied between 2.9 and $40.6 \mathrm{~g}$. (Table II).

TABLE II

DOSAGE AND DURATION OF CORTICOSTEROID THERAPY IN SEVEN PATIENTS WITH STILL'S DISEASE WHO DEVELOPED CATARACT

\begin{tabular}{|c|c|c|c|}
\hline \multirow[b]{2}{*}{ Case No. } & \multicolumn{2}{|c|}{ Steroid Dosage (Prednisone) } & \multirow{2}{*}{$\begin{array}{c}\text { Duration } \\
\text { of } \\
\text { Steroid } \\
\text { Therapy } \\
\text { (yrs) }\end{array}$} \\
\hline & $\begin{array}{c}\text { Total } \\
\text { (g.) }\end{array}$ & $\begin{array}{l}\text { Daily } \\
\text { Average } \\
\text { (mg.) }\end{array}$ & \\
\hline $\begin{array}{l}1 \\
2 \text { (left eye) } \\
3 \\
3 \\
4 \\
5 \\
6 \\
7\end{array}$ & $\begin{array}{r}12 \cdot 8 \\
2 \cdot 9 \\
7 \cdot 5 \\
12 \cdot 1 \\
24 \cdot 7 \\
40 \cdot 6 \\
10 \cdot 9 \\
6 \cdot 2\end{array}$ & $\begin{array}{r}9 \cdot 8 \\
6 \\
6 \\
4 \cdot 9 \\
13 \cdot 2 \\
20 \cdot 2 \\
8 \cdot 9 \\
4 \cdot 7\end{array}$ & $\begin{array}{l}3 \frac{1}{2} \\
1 \frac{1}{4} \\
3 \frac{1}{4} \\
5 \frac{3}{4} \\
5 \\
5 \frac{1}{2} \\
3 \frac{1}{4} \\
3 \frac{1}{2}\end{array}$ \\
\hline
\end{tabular}


In adults the first cataract was not detected until $2 \frac{3}{4}$ years after the institution of corticosteroid therapy and in the others after from 3 to 7 years of treatment: here the mean daily dose varied between 7.5 and $14.9 \mathrm{mg}$. daily, and total amount before the development of cataract varied from $8 \cdot 1$ to $29 \cdot 7 \mathrm{~g}$. prednisone or equivalent (Table III).

TABLE III

DOSAGE AND DURATION OF CORTICOSTEROID THERAPY IN SIX PATIENTS WITH RHEUMATOID ARTHRITIS WHO DEVELOPED CATARACT

\begin{tabular}{|c|c|c|c|}
\hline \multirow[b]{2}{*}{ Case No. } & \multicolumn{2}{|c|}{ Steroid Dosage (Prednisone) } & \multirow{2}{*}{$\begin{array}{c}\text { Duration } \\
\text { of } \\
\text { Steroid } \\
\text { Therapy } \\
\text { (yrs) }\end{array}$} \\
\hline & $\begin{array}{c}\text { Total } \\
\text { (g.) }\end{array}$ & $\begin{array}{c}\text { Daily } \\
\text { Average } \\
\text { (mg.) }\end{array}$ & \\
\hline $\begin{array}{r}8 \\
9 \\
10 \\
11 \\
12 \\
13\end{array}$ & $\begin{array}{r}29 \cdot 7 \\
19 \cdot 0 \\
25 \cdot 3 \\
12 \cdot 0 \\
8 \cdot 1 \\
16 \cdot 1\end{array}$ & $\begin{array}{r}14 \cdot 9 \\
11 \cdot 4 \\
9 \cdot 6 \\
7 \cdot 7 \\
7 \cdot 5 \\
13 \cdot 8\end{array}$ & $\begin{array}{l}5 \frac{1}{2} \\
4 \frac{1}{2} \\
7 \\
3 \frac{3}{4} \\
2 \frac{3}{4} \\
4\end{array}$ \\
\hline
\end{tabular}

For simplicity's sake all the corticosteroid therapy has been calculated in terms of $\mathrm{mg}$. prednisone, although some patients had received intermittent therapy with other corticosteroid drugs, such as cortisone, hydrocortisone, methylprednisolone, triamcinilone, dexamethazone, and betamethazone. With the relatively small numbers available, there was no evidence that different corticosteroid preparations had different effects on cataract formation.

It proved possible to calculate the total and average daily dose of corticosteroid from the case records and treatment sheets of all patients who developed this complication and in 48 others. The duration of therapy was not significantly different in the two groups, but the average daily dose of prednisone was somewhat higher, $11.5 \mathrm{mg}$. in those who developed cataract compared with $8.8 \mathrm{mg}$. in those who did not (Table IV). Separating the children from the adults, the difference in dosage between those who developed cataract and those who did not becomes a little more striking among the juveniles where the overall dosage is lower (Table V). However, despite the suggestion that

TABLE IV

PRESENCE OF CATARACT RELATED TO DURATION AND AMOUNT OF THERAPY

\begin{tabular}{c|c|c|c}
\hline $\begin{array}{c}\text { Posterior } \\
\text { Subcapsular } \\
\text { Cataract }\end{array}$ & $\begin{array}{c}\text { Patients } \\
\text { on } \\
\text { Corticosteroid } \\
\text { Therapy }\end{array}$ & $\begin{array}{c}\text { Average } \\
\text { Duration } \\
\text { of } \\
\text { Therapy } \\
\text { (yrs) }\end{array}$ & $\begin{array}{c}\text { Average Daily } \\
\text { Dosage } \\
\text { of } \\
\text { Prednisone } \\
\text { (mg.) }\end{array}$ \\
\hline Present & 13 & 41 & $11 \cdot 5$ \\
\hline Absent & 48 & 5 & 8.8 \\
\hline
\end{tabular}

TABLE $\mathrm{V}$

DIAGNOSIS AND PRESENCE OF CATARACT RELATED TO DURATION AND AMOUNT OF THERAPY

\begin{tabular}{c|c|c|c|c}
\hline Diagnosis & $\begin{array}{c}\text { Posterior } \\
\text { Subcapsular } \\
\text { Cataract }\end{array}$ & $\begin{array}{c}\text { No. } \\
\text { of } \\
\text { Cases }\end{array}$ & $\begin{array}{c}\text { Average } \\
\text { Duration of } \\
\text { Therapy } \\
\text { (yrs) }\end{array}$ & $\begin{array}{c}\text { Average } \\
\text { Daily } \\
\text { Dosage } \\
\text { (mg.) }\end{array}$ \\
\hline Still's Disease & Present & 7 & 4 & $10 \cdot 6$ \\
\cline { 2 - 4 } & Absent & 15 & 7 & $7 \cdot 7$ \\
\hline $\begin{array}{c}\text { Rheumatoid } \\
\text { Arthritis }\end{array}$ & Present & 6 & $4 \frac{1}{2}$ & $12 \cdot 2$ \\
\hline
\end{tabular}

dosage is important, eight of the thirteen affected $\stackrel{\omega}{\omega}$ patients had never received more than $10 \mathrm{mg}$. daily, so it is unwise to ignore the possibility of this complication in patients on low dosage schedules (Table VI).

TABLE VI

AVERAGE DOSAGE AND DURATION OF CORTICOSTEROID응 THERAPY IN THIRTEEN PATIENTS WITH POSTERIOR SUBCAPSULAR LENS OPACITIES

\begin{tabular}{|c|c|c|c|}
\hline \multirow{2}{*}{$\begin{array}{c}\text { Duration } \\
\text { of } \\
\text { Therapy } \\
\text { (yrs) }\end{array}$} & \multicolumn{3}{|c|}{ Average Daily Dosage } \\
\hline & Less than 10 & $10-15$ & More than 15 \\
\hline \multicolumn{4}{|l|}{ Under 1} \\
\hline 1 to 4 & 6 & 2 & \\
\hline 5 and More & 2 & 2 & 1 \\
\hline
\end{tabular}

Only two patients complained spontaneously of $\stackrel{\mathbb{2}}{2}$ any visual disturbance, although on direct question- $\overrightarrow{\overrightarrow{0}}$ ing, seven of the thirteen had mild disturbances of 3 vision, usually transient slight blurring or impaired long-distance vision. During the course of the year, vision has become increasingly impaired in the two patients who complained of symptoms.

\section{Discussion}

The incidence of cataract in the general population is extremely low, so that a report on a hospital in-o patient inquiry for the year 1958 (Sorsby, 1962)? shows an incidence of one cataract per 10,000 of theo general population in the 0 to 15 -year age group. The presence, therefore, of cataract in seven of 560 juveniles is very much greater than would be expected.N It has been suggested that this might be related to then underlying disease process rather than to therapy ${ }_{\sigma}^{\omega}$ However, over the last 16 years, over 300 children have been examined and cataract has been founc? only in those with chronic iridocyclitis or on corti-e costeroid therapy. In the control group of adults not receiving corticosteroid therapy, no cataracts were found, although the rheumatoid disease wasp classical and of moderate severity. 
The incidence of 11 per cent. in this series is low compared with that cited in the literature (Black and others, 1960; Oglesby and others, 1961). This may well be explained by the fact that this was an unselected group of patients and also by our policy of keeping corticosteroid dosage to a minimum level: it is extremely rare for patients here to receive $15 \mathrm{mg}$. or more of prednisone daily, the majority being maintained below $10 \mathrm{mg}$. daily. There does not seem to be any overall difference in cataract formation between the juvenile and the adult group, but it was found that children may develop this complication at a lower dose and in a shorter time. Thus, among the children, one patient on $6 \mathrm{mg}$. daily developed a cataract after $1 \frac{1}{4}$ years and a second one did likewise on $4.9 \mathrm{mg}$. daily after $5 \frac{3}{4}$ years, whereas in the adult group the shortest duration of time was $2 \frac{3}{4}$ years and the lowest dose $7 \cdot 5 \mathrm{mg}$. daily. However, taking the group as a whole, the difference between the average daily dose and duration of corticosteroid therapy between the patients with subcapsular cataract was not significant.

Once the clinician became used to looking for this complication it was found relatively easy to diagnose it at routine examination. As our observation of the patients suggests that cataract can develop quite quickly, i.e. in 2 to 3 months, it would seem that examination of the lens should form part of the routine 3-monthly check for patients on corticosteroid therapy even when they are maintained at a level below $10 \mathrm{mg}$. daily.

It is not sufficient to wait until patients complain of visual disturbance, as by this time the cataract is well developed. Our aim is to reduce the dose of corticosteroid as soon as any sign of lens change occurs and in a number in whom this has been done there has been no increase in the size of the opacities or deterioration in vision over 1 year.

Although only two patients in this unselected group experienced deterioration of vision, a number of patients receiving maintenance corticosteroid therapy for rheumatoid arthritis, and other chronic conditions such as asthma, have also been seen with this complication. In several of these cases removal of the steroid cataract (W.K.S.) has been required to restore vision when blindness threatened.

\section{Summary}

(1) A total of 113 patients, 56 children with Still's disease and 57 adults with classical rheumatoid arthritis, receiving maintenance corticosteroid therapy, was examined, together with 48 patients with classical rheumatoid arthritis not on corti- costeroids. Thirteen patients, seven with Still's disease and six with adult rheumatoid arthritis, were found to have posterior subcapsular lens opacities. These were all receiving corticosteroid therapy.

(2) The duration of therapy seemed to be less important than the average daily dose; while this tended to be higher in the patients developing cataract, particularly among the juveniles, eight of the thirteen cataracts occurred in patients whose daily dose of prednisone was $10 \mathrm{mg}$. or less.

(3) In the hope that cessation or reduction of steroid administration may inhibit or slow down the progress of an early cataract, this condition must be looked for routinely and repeatedly in patients on corticosteroids. If there is any suggestion of an opacity, the patients should be referred to an ophthalmologist.

\section{REFERENCES}

American Rheumatism Association Committee (1959). Ann. rheum. Dis., 18, 49.

Ansell, B. M., and Bywaters, E. G. L. (1959). Bull. rheum. Dis., 9, 189.

Black, R. L., Oglesby, R. B., von Sallmann, L., and Bunim, J. J. (1960). J. Amer. med. Ass., 174, 166.

Crews, S. J. (1963). Brit. med. J., 1, 1644.

Hart, F. Dudley, Casey, T. A., and O'Riordan, M. D. (1961). Ibid., I, 1680.

Oglesby, R. B., Black, R. L., von Sallmann, L., and Bunim, J. J. (1961). Arch. Ophthal. (Chicago), 66, $519,625$.

Pfahl, S. B., Makley, T. A., McCoy, F. W., and Rothermich, N. O. (1961). Amer. J. Ophthal., 51, 710.

Smiley, W. K., May, E., and Bywaters, E. G. L. (1957). Ann. rheum. Dis., 16, 371.

Sorsby, A. (1962). Exp. Eye Res., 1, 296.

Toogood, J. H., Dyson, C., Thompson, C. A., and Mularchyk, E. J. (1962). Canad. med. Ass. J., 86, 52.

\section{La cataracte stérö̈de}

\section{RÉSUMÉ}

(1) On a examiné 56 enfants atteints de maladie de Still et 57 adultes souffrant d'arthrite rhumatismale $\mathcal{N}$ classique, en tout 113 malades soumis au régime corticostéroïde d'entretien ainsi que 48 autres malades $N$ atteints d'arthrite rhumatismale classique mais ne $\underset{\omega}{N}$ recevant pas de corticostérö̈des. On a trouvé que 13 malades, dont sept atteints de maladie de Still et six adultes atteints d'arthrite rhumatismale présentaient des $O$ opacités sous-capsulaires posterieures du cristallin. Tous $\mathbb{\mathbb { D }}$ ces malades étaient au régime corticostéroïde.

(2) La durée de la thérapie semblait être moins 무 importante que la dose moyenne par jour; bien que $\overrightarrow{0}$ celle-ci tendait à être plus forte chez les malades qui $\underset{\mathbb{D}}{\mathbb{D}}$

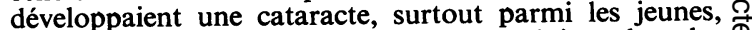
huit sur les treize cataractes se sont produites chez des $\stackrel{\varnothing}{\varnothing}$ 
malades qui recevaient $10 \mathrm{mg}$. de prednisolone ou moins par jour.

(3) En espérant que l'interruption ou la réduction de la thérapie stéroïde puisse inhiber ou ralentir la formation d'une cataracte naissante, il faut rechercher cette condition régulièrement et à maintes reprises et, au moindre soupçon, consulter un ophtalmologiste.

\section{La catarata esteroide}

\section{Sumario}

(1) Se examinaron 56 niños con enfermedad de Still y 57 adultos con artritis reumatoide clásica, un total de 113 enfermos, sometidos a la terapia corticosteroide de sostén, así como 48 enfermos con artritis reumatoide clásica que no recibían corticosteroides. En trece enfermos - siete con enfermedad de Still y seis adultos con artritis reumatoide-se encontraron opacidades subcapsulares posteriores del cristalino. Todos estos enfermos recibían corticosteroides.

(2) La duración del tratamiento pareció tener menor importancia que la dosis diaria media: aunque ésta tendió ser más fuerte en enfermos que desarrollaron catarata, particularmente en los jóvenes, ocho de las trece cataratas se produjeron en enfermos recibiendo 10 mg. o menos de prednisolona al día.

(3) En la espera de que la interrupción o la reducción de la terapia esteroide pueda inhibir o retardar la formación de una catarata naciente, se debe buscar esta condición regular y repetidamente y, a sospechar una opacidad, consultar el oculista. 